\title{
ACCESSIBILITY DEVELOPMENT: A GUIDE TO SUSTAIN MODERN MARKET FOR URBAN SHOPPER'S DIVERSITY
}

\author{
Novita Indah Mulyaningrum ${ }^{1 *}$, Nurul Sukma Lestari ${ }^{1}$, Rachel Dyah Wiastuti ${ }^{1}$ \\ ${ }^{1}$ Bina Nusantara University, Hotel Management Departement, \\ Faculty of Economic and Communication \\ *novitaindahm.edu@gmail.com
}

\begin{abstract}
Modern market has been defined as the needs of urban shoppers in providing the grocery shopping and fulfilling the shopping demands. In addition, changes in the diverse shoppers, lead to diverse market desire to acquire more convenient place to shop. Therefore, accessibility should be a key issue to this consideration that eventually will be able to enhance the shopper experience. This study aims to identify the accessibility implementation in term of common requirements of Jakarta's modern market based on World Tourism Organization Accessible Tourism concept. This research used qualitative method with explorative approach. Research object was chosen based on modern market data listed in Jakarta Culture and Tourism Board official website retrieved on January $10^{\text {th }}, 2018$. Primary data were collected through interview and direct filed observation on eight modern markets in Jakarta. The finding elaborates accessibility implementation in terms of common requirements based on seven criteria; parking area, communication, signage, horizontal movement, vertical movement, public hygiene and prices. The results show communications criteria are less implemented and signage criteria are implemented the most by majority modern market. This study implication will be beneficial in providing recommendation for modern market to be able to sustain the business through maximizing the common requirements of accessibility to meet the needs of diverse urban shopper.
\end{abstract}

Keywords: Accessibility, tourism, modern market, urban shopper

\section{INTRODUCTION}

In a world of tourism, any object, person, place, or concept that draws people experience is called as an attraction (Stange \& Brown, 2013). As a capital city, Jakarta province government begin to develop tourist attraction to fulfil the tourism demand and to meet the visitor expectation (Adiati, Lestari, \& Wiastuti, 2018).Tourism itself is a diverse industry which acts as a central economic driver for the development in several areas and destinations throughout the world (UNWTO, 2011). One of the popular urban attraction for the tourist and its citizen is the modern market (Natawidjaja, 2005).

A modern market is a self-service system that is implemented by the store, offering various types of products retail, in a form as Minimarket, Supermarket, Department Store, Hypermarket, Grocery or wholesale (Masruroh, 2017). Supermarkets and hypermarkets are expanding fast in many developing countries (Schipmann \& Qaim, 2011). This is due to people assume that modern markets are cleaner, neat and well organized than traditional market (Seminari, Rastini, \& Sulistyawati, 2017). The development of modern markets in Indonesia is growing rapidly and reach to $31.4 \%$ per year (Prabowo, Madi, Safri, \& Lustrilanang, 2017), thus accessibility development initiatives must be considered (Wiastuti, Adiati, \& Lestari, 2018). Accessibility is crucial to note as it is about designing a good experience that works well for everyone (UNWTO, 2016). Accessibility must be enjoyed and felt by everyone including by people with special needs, where they can feel the same thing with others without having to depend on others (Darcy \& Dickson, 2009). Eventually, accessibility will bring advantages for everyone (Ki, 2016). Therefore, providing accessibility will deal with both challenge and opportunity for the destinations to enhance its tourism quality (Silvia, 2013). Accessibility will impact as well to the economic factor of the tourism industry (Luiza, 2010). 
In regards to sustaining the modern market as a part of attraction in tourism industry, the accessibility must be well develop to meet the needs of urban shopper's diversity. This study aims to identify the accessibility implementation in term of common requirements of Jakarta's modern market based on UNWTO Accessible Tourism concept. This paper will answer two research questions; (1) to what extent the seven criteria of common requirements accessibility are implemented by modern market? and (2) what are the common requirements accessibility criteria that implemented the most and the least by majority of modern market?

\section{THEORETICAL FRAMEWORK}

\section{Tourism for All}

Tourism for all is an obligation of all parties including the several companies who provide tourism services and that must be regulated by the government (UNWTO, 2015). Tourism for all can be defined as an accessible, sustainable, and equitable contribution for everyone (Wiastuti, Adiati, \& Lestari, 2018).

\section{Accessible Tourism}

Every tourist with disability has a same right with general people to experience the tourism product and service without any restriction in wherever they are (Khatri, Shrestha, \& Mahat, 2012). Accessible tourism can be defined as tourism for all, not only about the location in general meaning but also people with dissability can be more comfortably in doing their tourism activity(Bindu \& Devi, 2016). The demand for a more accessible tourism is growing fast (Buj, 2010) and accessibility development initiatives must be considered (Wiastuti, Adiati, \& Lestari, 2018) . Thus, the concept of accessible tourism is defined into seven criteria; parking areas, communication, signage, horizontal movement, vertical movement, public-hygiene and prices (UNWTO, 2013).

The common requirements that tourism facilities and sites should comply consist of seven criteria; parking area, communication, signage, horizontal movement, vertical movement, public hygiene and prices.

(a) Parking Areas. There should be special parking spaces with proper identification for vehicles of persons with reduced mobility. Individual parking spaces should be wide enough for passengers with disabilities to manoeuvre comfortably between cars and wheelchairs, and shall be located so that persons using wheelchairs, crutches or prostheses are not obliged to go around cars. Where there are access roads to the building or site, these should be safe for all pedestrians (UNWTO, 2013). A tightly accessible car park is provided for parking permit holders for people with disabilities (Meath County Council).

(b) Communication. More and more literature on "accessible tourism" has no critical scientific debate about the use of language and its nomenclature (22) (Gillovic, McIntosh, Darcy, \& Cockburn-Wootten, 2018). The use of sign language, Braille, and augmentative and alternative ways, means and modes of communication and all other ways, means and formats of communication chosen by persons with disabilities should be accepted and facilitated (UNWTO, 2013)

(c) Signage. The information, check-in and ticket sales counters should be clearly marked and have an accessible area reserved for use by persons with reduced mobility located as close as possible to the entrance. Announcements should be both visual and audible. Fire alarms should emit both visual and acoustic signals. The marking of emergency exits must be clear and well lit (UNWTO, 2013). A series of references are given to inform guidelines about the accessibility in universal term (Chikuta, Plessis, \& Saayman, 2018)

(d) Horizontal Movement. Main corridors and passageways should be free of physical and visual barriers and have a width to permit the passage of two wheelchairs side-by-side, such that they are not blocked in normal circulation, or otherwise provide passing points(UNWTO, 2013). The arrangements must be made so that people with disabilities can move freely (Lestari, Wiastuti, \& Adiati, 2017).

(e) Vertical Movement. Elevators wide enough for a person using a wheelchair to enter and move easily, it also specially designed and equipped for easy use by such persons and for the blind, and should be equipped with emergency systems accessible to the hearing impaired. Moreover, the built environment should be at the same level or equipped with ramps where there is a change in floor levels (UNWTO, 
2013). Vertical movement is the difference in the height of the road must be no gap because every element such as a ladder must be designed according to the parameters that have been determined (Lestari, Wiastuti, \& Adiati, 2017)

(f) Public-Hygiene. Accessible toilet stalls and washbasins should also be installed for people with wheelchair and equipped with a system which provided to allow persons inside the toilet stalls to find and use emergency lighting signs and switches (UNWTO, 2013). The provision of public toilets is important to see also in terms of their usefulness ( Afacan \& Gurel, 2015).

(g) Prices. Additional costs required to provide accessible services and facilities shall not entail an increase in rates for customers with disabilities. (UNWTO, 2013). Every product of tourism must be planned for all age, gender and ability and without additional fees for disabled and special customers access requirements (UNWTO, 2016).

\section{Modern Market}

Modern markets are market managed by modern management, generally in urban areas, as a provider of goods and services which has a good quality and service for consumers (Sinaga, 2006). Modern market such as hypermarket and supermarket start to chosen by urban shopper because of its convenience and cleanliness (Sunanto, 2012). Modern market is become a new culture and lifestyles for city urban shopper, the culture has consciously taught urban shopper to live more pragmatic and practical in accordance with cultural theory, which new culture gradually indirectly will eliminate the old culture that already exists (Kartika, Hani, \& Hartadi, 2010). Modern market is a market that puts its goods in groups according to the same uses, can be seen and taken immediately by buyers, using air conditioners, and the hire salesman (Nelwan, Rumokoy, \& Lapian, 2017)

\section{Urban Shopper}

Shopper is someone who buys items from a store or several shops (35) (Cambridge Dictionary). Metropolitan area, cities, and the surrounding area of the city can be referring to urban area (National Geographic). So it can be said that people who live in cities and make purchases in shops are urban shopper.

\section{METHOD}

A qualitative method with an explorative approach is used in this study to elaborate the implementation of accessible tourism in terms of common requirements in Jakarta modern market. Qualitative research is conducted because the style of the research tries to construct reality and understand its meaning that mostly concern with processes, events and authenticity (Somantri, 2005). Research object was retrieved from Jakarta Tourism and Culture Board official website (www.jakartatourism.go.id) on January $10^{\text {th }}, 2018$ in See \& Do menu, specify in shopping activity. Shopping activity in Jakarta Tourism Board are consist of four places; mall, traditional market, modern market and special market. This research is focus only to one of the shopping activity in modern market. As a result, eight modern market brands were gathered; Carrefour, Giant, Hero Supermarket, Hypermart, LotteMart, Matahari Department Store, Ramayana Department Store, and Superindo. To further assign the research object, two locations from each modern market brand was allocate, thus 16 modern market from eight brands was define as the research object that can be seen in Table 1. Modern market location was chosen based on convenience sampling method. 
Table 1. List of modern market as research object

\begin{tabular}{|c|c|c|c|c|}
\hline No & Modern Market & $\mathrm{Abb}$ & Address & Area \\
\hline 1 & Carrefour & $\mathrm{CF}$ & $\begin{array}{l}\text { Jalan Lebak Bulus Raya No.8 } \\
\text { Pondok Pinang, Kebayoran Lama } \\
\text { Jakarta } 12310\end{array}$ & South Jakarta \\
\hline 2 & Carrefour & $\mathrm{CF}$ & $\begin{array}{l}\text { Central Park Mall, Jalan Letjen S. Parman } \\
\text { No.28, Tanjung Duren Selatan } \\
\text { Grogol Petamburan. Jakarta } 11470\end{array}$ & West Jakarta \\
\hline 3 & Giant & GT & $\begin{array}{l}\text { Poins Square- Ground Floor } \\
\text { Jl. R.A.Kartini No. 1. Lebak Bulus } \\
\text { Cilandak. Jakarta } 12440\end{array}$ & South Jakarta \\
\hline 4 & Giant & GT & $\begin{array}{l}\text { Blok M Plaza, J1. Bulungan No.78 } \\
\text { Kramat Pela. Kebayoran Lama } \\
\text { Jakarta } 12130\end{array}$ & South Jakarta \\
\hline 5 & Hero Supermarket & HS & $\begin{array}{l}\text { Ciputra Mall- Upper Ground Floor } \\
\text { Jalan Letjen. S. Parman. } \\
\text { Grogol Petamburan. Jakarta } 11470\end{array}$ & West Jakarta \\
\hline 6 & Hero Supermarket & HS & $\begin{array}{l}\text { Puri Indah Mall- Ground Floor } \\
\text { Puri Agung, Kembangan Selatan } \\
\text { Jakarta } 11610\end{array}$ & West Jakarta \\
\hline 7 & Hypermart & $\mathrm{HM}$ & $\begin{array}{l}\text { Cibubur Juction- Lower Ground } \\
\text { Jalan Jambore No.1 } \\
\text { Cibubur, Ciracas. Jakarta } 13720\end{array}$ & East Jakarta \\
\hline 8 & Hypermart & $\mathrm{HM}$ & $\begin{array}{l}\text { Pejaten Village Mall, } \\
\text { Jalan Warung Jati Barat No. } 39 \\
\text { Pasar Minggu. Jakarta } 12510\end{array}$ & South Jakarta \\
\hline 9 & LotteMart & LM & $\begin{array}{l}\text { Gandaria City Mall- Lower Ground } \\
\text { Jalan Sultan Iskandar Muda } \\
\text { Kebayoran Lama Utara. Jakarta } 12240\end{array}$ & South Jakarta \\
\hline 10 & LotteMart & LM & $\begin{array}{l}\text { Kuningan City Mall- Lower Ground } \\
\text { Jalan Professor Doktor Satrio No.18 } \\
\text { Karet Kuningan. Jakarta } 12940\end{array}$ & South Jakarta \\
\hline 11 & $\begin{array}{l}\text { Matahari } \\
\text { Store }\end{array}$ & MS & $\begin{array}{l}\text { Cibubur Juction- Lower Ground } \\
\text { Jalan Jambore No.1 } \\
\text { Cibubur, Ciracas. Jakarta } 13720\end{array}$ & East Jakarta \\
\hline 12 & $\begin{array}{l}\text { Matahari } \\
\text { Store }\end{array}$ & MS & $\begin{array}{l}\text { Mall Ciputra - } 2^{\text {nd }} \text { Floor } \\
\text { Jalan Letjen S. Parman. Tanjung Duren } \\
\text { Grogol Petamburan. Jakarta } 11470\end{array}$ & West Jakarta \\
\hline 13 & $\begin{array}{l}\text { Ramayana Departement } \\
\text { Store }\end{array}$ & RS & $\begin{array}{l}\text { Pasar Palmerah- } 1^{\text {st }} \text { Floor } \\
\text { Jalan Palmerah Barat No. } 2 \\
\text { Jati Pulo. Jakarta } 51129\end{array}$ & Central Jakarta \\
\hline 14 & $\begin{array}{l}\text { Ramayana Departement } \\
\text { Store }\end{array}$ & RS & $\begin{array}{l}\text { Graha Cijantung Mall- Ground Floor } \\
\text { Jalan Raya Bogor. Cijantung } \\
\text { Pasar Rebo. Jakarta } 13770\end{array}$ & East Jakarta \\
\hline 15 & Superindo & $\mathrm{SP}$ & $\begin{array}{l}\text { Jalan Raya Pos Pengumben } \\
\text { Perumahan Villa Kelapa Dua } \\
\text { Kebun Jeruk. Jakarta } 11560\end{array}$ & West Jakarta \\
\hline 16 & Superindo & $\mathrm{SP}$ & $\begin{array}{l}\text { Kantor Pusat PT. PP } \\
\text { Jalan TB Simatupang No. } 57 \\
\text { Gedong. Pasar Rebo. Jakarta } 13760\end{array}$ & East Jakarta \\
\hline
\end{tabular}

Source: Jakarta Tourism Board, 2018

Primary data collection was done through observation and interviews. Secondary data is collected from documentation and literature studies. The direct field observation was conduct within two months period, from January 2018 to March 2018 by three researchers with the objective to obtain the accessible tourism implementation in terms of common requirements in all research objects. Researcher took up four to five hours observe each modern market. An observation checklist prepared as a guideline. The observation checklist gives a guidance to cover all indicators of accessible tourism. The observation check list consists of eight parts; (1) general information of modern market, day, date 
and time of observation conducted, (2) parking areas checklist and notes, (3) communication checklist and notes, (4) signage checklist and notes, (5) horizontal movement checklist and notes, (6) vertical movement checklist and notes, (7) public-hygiene checklist and notes, and (8) prices checklist and notes. Documentation was conduct in the same time with observation, by taking note in the observation check list, taking photo, and all relevant documents regards to the accessibility indicators, such as brochure, marketing tools, membership, and price list. Once the observation was completed, researcher collect and analyse all observation checklists, together with the finding data from the documentation, photo, and others document (Arikunto, 2010)

\section{Findings and Discussion}

Results are elaborated in seven subsections referring to accessible tourism in common requirements criteria. Furthermore, discussion is defined after the findings. Each modern market name is abbreviated according to Table 1.; Carrefour as CF, Giant as GT, Hero Supermarket as HS, Hypermart as HM, LotteMart as LM, Matahari Department Store as MS, Ramayana Department Store as RS, and Superindo as SP.

\section{Parking Area}

Regards to parking area findings, all modern market has parking area; to mention CF, GT, HS, HM, LM, MS, RS, SP. However, there is a difference for modern market which embedded with shopping mall and stand-alone modern market. There are 12 modern market that located inside the shopping malls, such as CF Central Park, GT Poins Square, GT Blok M Plaza, HS Ciputra, HS Puri, HM Cibubur Junction, HM Pejaten Village, LM Gandaria City, LM Kuningan City, MS Cibubur Junction, MS Ciputra and RS Graha Cijantung Mall. Meanwhile, there are 4 stand-alone modern market such as CF Lebak Bulus, RS Pasar Palmerah, SP Pos Pengumben and SP Kantor Pusat PT.PP.

The difference of parking area took place because modern market inside the shopping mall have adequate parking area consists of motorcycle parking and car parking area (in CF Central Park, GT Poins Square, GT Blok M Plaza, HS Ciputra, HS Puri, HM Cibubur Junction, HM Pejaten Village, LM Gandaria City, LM Kuningan City, MS Cibubur Junction, MS Ciputra and RS Graha Cijantung Mall), Bus parking area are available in CF Central Park, GT Poins Square, GT Blok M Plaza, HS Ciputra, HS Puri, HM Cibubur Junction, LM Kuningan City, MS Cibubur Junction and MS Ciputra. Bicycle parking area are available in CF Central Park, LM Gandaria City and LM Kuningan City. Ladies parking, disable parking and valet service are available in CF Central Park, GT Blok M Plaza, HS Ciputra, HS Puri, HM Cibubur Junction, HM Pejaten Village, LM Gandaria City, LM Kuningan City, MS Cibubur Junction, and MS Ciputra.

Furthermore, parking area for stand-alone modern market are also equipped for motorcycle and cars. However, there is no valet service or ladies parking facilities. HM Pejaten Village that located inside Pejaten Village Mall have an adequate parking area, but the turn in point of car parking area is too sharp thus give difficultness for drivers when park the car. The disable parking area is too narrow as well. Meanwhile, even though CF Lebak Bulus has parking area for disability, it is not located near the main entrance. In addition, the motorcycle parking space in CF Lebak Bulus is quite narrow, thus provide no adequate space for the customer to move forward and to move around in the parking area once the lot is fully occupied.

\section{Communication}

Regards to communication findings, all aspects of communication such as the use of sign language, braille and augmentative and alternative are not yet applied comprehensively. Braille key button can be found in elevator at 12 modern market inside the shopping mall; CF Central Park, GT Poins Square, GT Blok M Plaza, HS Ciputra, HS Puri, HM Cibubur Junction, HM Pejaten Village, LM Gandaria City, LM Kuningan City, MS Cibubur Junction, MS Ciputra and RS Graha Cijantung Mall. Another findings in communication also seen in regards to product price tag. This price tag is in each product shelves and available in two forms; hand-written font style and typed font style. All price tag can be seen clearly and located near the products. Four out of eight modern market applies hand-written font style; GT, HS, RS, and SP. While, CF, LM, MS, HM applies typed font style. Finding in 
communication also identified about the audio announcement. The audio announcement is carried out for two purposes; first is to inform the shopper about available promotion in modern market, and second is to call the modern market employee to present in particular venue as requested. The audio announcement can be heard in Bahasa Indonesia at all modern market throughout the day.

\section{Signage}

Regards to signage findings, brand name signage of modern market inside the shopping mall are attached in shopping mall's main building and in entrance of modern market. This is applying to 12 modern markets; CF Central Park, GT Poins Square, GT Blok M Plaza, HS Ciputra, HS Puri, HM Cibubur Junction, HM Pejaten Village, LM Gandaria City, LM Kuningan City, MS Cibubur Junction, MS Ciputra and RS Graha Cijantung Mall. Meanwhile, brand name signage for stand-alone modern market is attached in main building and as a standing signage in front of the building. All signage is clearly seen. This is applying to four modern markets; CF Lebak Bulus, RS Pasar Palmerah, SP Pos Pengumben and SP Kantor Pusat PT.PP. Directional signage to locate the emergency and toilet are available in all modern market, can be seen clearly, comply universal design and with pictogram. Meanwhile, directional signage to locate the modern market location inside the shopping mall is also available. This signage useful for the shopper to find the market once they are entering the mall. This signage applies in CF Central Park, GT Poins Square, GT Blok M Plaza, HS Ciputra, HS Puri, HM Cibubur Junction, HM Pejaten Village, LM Gandaria City, LM Kuningan City, MS Cibubur Junction and MS Ciputra.

Information signage about product category section are locate higher than the product shelves, thus can be seen clearly by shopper. This information signage complies in English language for five modern market (CF, HM, HS, LM, MS), while three modern complies in Indonesia language (RS, SP, GT). Furthermore, all modern market equipped with clear signage for fire extinguisher, except for RS Palmerah. The fire extinguisher itself locate with no barrier so that can be access without further obstacle.

\section{Horizontal Movement}

Regards to horizontal movement findings, CF, HM, HS, LM and GT have appropriate alley between rack with space for two trolleys passing by. On the contrary, MS, RS and SP have narrow alley between rack with only space for two people walking and passing by. In addition, RS Pasar Palmerah has a surface gap in the floor about $3 \mathrm{~cm}$.

\section{Vertical Movement}

Regards to vertical movement, findings can only be elaborate for more than one story establishment. There is 14 modern market that consist of only one story, thus will not be further discuss in this section;

CF Central Park, GT Poins Square, GT Blok M Plaza, HS Ciputra, HS Puri, HM Cibubur Junction, HM Pejaten Village, LM Gandaria City, LM Kuningan City, RS Graha Cijantung Mall, CF Lebak Bulus, RS Pasar Palmerah, SP Pos Pengumben and SP Kantor Pusat PT. PP. There is two modern market that comply with more than one story; MS Cibubur Junction and MS Ciputra, that further will be elaborate. Both are equipped with one escalator up and one escalator down inside of the market for connecting between floor. The escalator is in good condition with several instructions on the escalator entrance. This escalator provide accessibility for the shoppers to be able to move around between each floor without the need to find lift or escalator outside the market. This facility make visitor more convenience to shop.

To access the modern market inside the shopping mall, elevator, escalator and stairs are provided from the mall main entrance, from different floor, and from the parking area. This facility applies in CF Central Park, GT Poins Square, GT Blok M Plaza, HS Ciputra, HS Puri, HM Cibubur Junction, HM Pejaten Village, LM Gandaria City, LM Kuningan City, and RS Graha Cijantung Mall. To access standalone modern market, elevator, escalator and stairs are also provided from the market main entrance and from the parking area. This facility applies in CF Lebak Bulus, RS Pasar Palmerah, SP Pos Pengumben and SP Kantor Pusat PT. PP. However, CF Lebak Bulus provide different facility to make shopper more convenience, named as vertical or inclined moving walkways. This facility replaces the elevator function. This vertical moving walkways was identified located in a corner of the 
level. In addition, Pasar Palmerah provide with only stairs from the ground main entrance to the first floor, and further continue with two level escalator to finally reach RS Palmerah.

\section{Public Hygiene}

Regards to public-hygiene findings, modern market inside of shopping mall have an adequate public toilet for male and female with clear signage; applies in 12 modern markets; CF Central Park, GT Poins Square, GT Blok M Plaza, HS Ciputra, HS Puri, HM Cibubur Junction, HM Pejaten Village, LM Gandaria City, LM Kuningan City, MS Cibubur Junction, MS Ciputra and RS Graha Cijantung Mall. Disable toilet are also provided in above 12 modern market except in GT Blok M Plaza, MS Ciputra and RS Graha Cijantung Mall. The public toilets are equipped with wash-basin, soap dispenser and hand-dryer machine or paper napkin. Due to its location inside the shopping mall, CF Central Park has large number of toilet, with an average number of 8 to 10 rooms for each toilet. Aside from public toilet and disable toilet, eight modern market equipped with baby room; CF Central Park, GT Blok M Plaza, HS Ciputra, HS Puri, HM Pejaten Village, LM Gandaria City, LM Kuningan City, and MS Ciputra. All of public hygiene for modern market inside of shopping mall is a part of shopping mall's facilities. Most of those public hygiene are located on left and right side corner of mall, near from the modern market location. Meanwhile, four stand-alone modern market, CF Lebak Bulus, RS Pasar Palmerah, SP Pos Pengumben and SP Kantor Pusat PT.PP, also provide public toilets for male and female, but without baby room and disable toilet. Only CF Lebak Bulus equipped with disable toilet and baby room.

\section{Prices}

Regards to prices findings, all modern market applies no additional fee for all shopper. Anyone can enter the modern market without pay any entrance fee, no matter it is shopper who came with family, solo, with children, elderly, and with disabilities. Shopper who come with luggage simply need to go to the deposit counter to put their luggage with no additional charge. Modern market inside of shopping mall does provide children trolley on request basis for shopper who come with children. Shopper require to give their identity card as a guarantee. This system applied the same to five modern market; CF Central Park, GT Poins Square, HM Cibubur Junction, HM Pejaten Village and LM Gandaria City. Upon arrival, shopper simply need to go to the section provide this children trolley, handed the identity card, get the children trolley that can be borrowed at any time, and returned the children trolley to get back the identity card. Surprisingly, this facility provided in complimentary basis, thus no additional charge required. It can be request by anyone disregards the purchasing power. Though, the quantity of the children trolley is limited. Once it is out of stock, shopper need to wait for another children trolley used by other shopper. However, CF Lebak Bulus that is not embedded with shopping mall also provide this facility.

Another facility provided in a complimentary basis is wheelchair rental. This facility can be found in modern market that embedded with shopping mall; CF Central Park, GT Poins Square, GT Blok M Plaza, HS Ciputra, HS Puri, HM Cibubur Junction, HM Pejaten Village, LM Gandaria City, LM Kuningan City, MS Cibubur Junction, MS Ciputra and RS Graha Cijantung Mall. However, a deposit of 100.000 IDR to 150.000 IDR is required as a guarantee and will be fully returned upon handed back the wheelchair. The quantity is very limited, with only one to two wheelchairs for each establishment. Though the deposit fee is not that cheap, but it is still affordable compare to the price for the wheelchair itself. However, CF Lebak Bulus that is not embedded with shopping mall also provide this facility. Meanwhile, stand-alone modern market; RS Pasar Palmerah, SP Pos Pengumben and SP Kantor Pusat PT.PP, provide no rental facilities for children trolley or wheelchair.

\section{RESULT AND DISCUSSION}

In terms of parking area, all modern market comply with parking space. Some are provided with both car and motorcycle parking area, and some are provided without bicycle park. Apart from the parking space for various vehicle type (car, motorcycle, bicycle, bus), disable parking space should took place as main consideration as well. Additional facilities such as female parking and valet service will eventually acquire convenience for the shoppers. Though parking matter seems to be a minor issue, however shopper will consider this facility as one of shopping attributes. CF Central Park, LM Gandaria 
City, LM Kuningan City, MS Cibubur Junction, HM Cibubur Juntion find out to be modern market that have good parking facilities.

In terms of communication, the use of sign language, braille, augmentative and alternative ways should be facilitated (UNWTO, 2013). Moreover, other public communication systems, such as sound amplification and the formats in which information is provided shall be designed and made available for public. The product price tag is available in each product shelves and written in two forms; handwritten font style and typed font style. All price tag can be seen clearly and located near the products. Audio announcement can also be found in all modern market though the used language is only in Bahasa Indonesia.

In terms of signage, services signage and facilities signage should be clearly marked with easy understandable symbols of an appropriate size and colour which contrasts with the background (UNWTO, 2013).. In all modern market, the brand signage is clearly seen. But, in five of eight modern markets (CF, HM, HS, LM, MS), product category information is mostly written in English. This language may become barrier for shoppers who do not understand English. Directional signage to locate the emergency and toilet are available in all modern market, can be seen clearly, comply universal design and with pictogram.

In terms of horizontal movement main corridors and passageways should be free from barriers and effective measures should be taken to ensure that persons with disabilities are able to move around the venue (UNWTO, 2013). Finding shows that all modern market has no barrier in horizontal movement, shopper can move around easily, but it turns out MS, RS, SP have narrow alley or corridor between shelves that impact to shopper convenience while moving around. In terms of vertical movement, the built environment should be at the same level or equipped with ramps where there is a change in floor levels and multi-storey structures should have an adequate number of elevators wide enough for a person using a wheelchair to enter and move easily (UNWTO, 2013).. In MS Ciputra, the escalator has $50 \mathrm{~cm}$ gap with the floor. Moreover, RS Pasar Palmerah can only be access by stair for one floor. This stair will become barrier for elder people or pregnant women to reach the level. But, for accessing inside to modern market which embedded with shopping mall, elevator, escalator and stairs are provided from the mall main entrance, from different floor, and from the parking area.

In terms of public hygiene, toilet is provided in all modern market, despite located inside the modern market or inside the shopping mall. The available toilet room is decent for both male and female. Toilet is also equipped with amenities for shopper perusal. Additional public hygiene facilities such as baby room, pumping room and disable toilet indeed should be provided. However, some modern market does not equipped with these additional facilities. It turns out CF Central Park, LM Gandaria City, and LM Kuningan City provide the most good public hygiene facilities. In terms of prices, additional costs required to provide accessible services and facilities shall not entail an increase in rates for customers with disabilities (UNWTO, 2013). It is identified that anyone can enter the modern market without pay any entrance fee, no matter it is shopper who came with family, solo, with children, elderly, and with disabilities. Other than that, for shopper who needs to rent children trolley or wheelchair, the facilities provided in complimentary with no additional charge

\section{CONCLUSION}

All Jakarta's modern markets do not implement the common requirement accessibility concept from UNWTO comprehensively. Signage become the most implemented criteria, while communication become the least implemented criteria by majority of Jakarta's modern market. Meanwhile, three out of seven criteria of common requirements; vertical movement, public-hygiene and communication, need a lot of improvement. Carrefour Central Park and Carrefour Lebak Bulus act as a good example of modern market that applicate the common requirement accessibility. On the contrary, Ramayana Graha Cijantung and Ramayana Pasar Palmerah found out to be applicate the least of common requirement accessibility. Suggestion for the modern market is to provide ramps and adequate elevator aside from available stairs and to ensure no gap in the floor surface. Parking area need to be well arranging to assure shopper able to park their vehicle comfortably. Product information signage should comply in minimum dual language; English and Indonesia. Employee training can be provided to facilitate shopper with hearing disability. The recommendation of accessibility development for those several modern market to be able to sustain thee business to meet the needs of diverse urban shopper. 
Future research can be conduct by using five accessible tourism dimensions; information, transportation, common requirements, universal design and accessibility.

\section{ACKNOWLEDGMENT}

This research is a part of Bina Nusantara University Research Grant 2018. Researcher would like to thank you to Bina Nusantara University and all previous relevant researchers in the same field.

\section{REFERENCES}

Afacan, Y., \& Gurel, M. O. (2015). Public toilets: an exploratory study on the demands, needs, and expectations in Turkey. Environment and Planning B: Planning and Design Vol. 42 Issue 2, 242-262.

Nelwan, J. W., Rumokoy, F. S., \& Lapian, J. (2017). The Existence of Traditional Market Toward Modern Market in Tomohon City. Jurnal Riset Ekonomi, Manajemen, Bisnis dan Akuntansi Vol. 5 No.3, 3348 - 3355.

Adiati, M. P., Lestari, N. S., \& Wiastuti, R. D. (2018). Public parks as urban tourism in Jakarta. IOP Conference Series: Earth and Environmental Science (pp. 1-8). Medan: IOP.

Arikunto, S. (2010). Prosedur Penelitian: Suatu Pendekatan Praktik. Jakarta: Rineka Cipta.

Bindu, V. T., \& Devi, M. K. (2016). Accessible Tourism: Determinants and Constraints; A Demand Side Perspective. IOSR Journal of Business and Management (IOSR-JBM) Vol.18 No.9,18.

Buj, C. (2010). Paving the Way to Accessible Tourism. Leeds: International Centre for Responsible Tourism Leeds Metropolitan University.

Cambridge Dictionary. (n.d.). Cambridge Dictionary. Retrieved September 01, 2018, from Cambridge Dictionary: https://dictionary.cambridge.org/dictionary/english/shopper

Chikuta, O., Plessis, E. d., \& Saayman, M. (2018). Accessibility Expectations of Tourists with Disabilities in National Parks. Tourism Planning \& Development. doi:10.1080/21568316.2018.1447509

Darcy, S., \& Dickson, T. J. (2009). A Whole-of-Life Approach to Tourism: The Case for Accessible Tourism Experiences. Journal of Hospitality and Tourism Management Vol.16 Issue 1, 3244.

Gillovic, B., McIntosh, A., Darcy, S., \& Cockburn-Wootten, C. A. (2018). Enabling the language of accessible tourism. Journal of Sustainable Tourism, 1-16. doi:10.1080/09669582.2017.1377209

Kartika, N. D., Hani, E. S., \& Hartadi, R. (2010). Analisis Perilaku Konsumen Buah di Pasar Tradisional dan Pasar Modern Kecamatan Kaliwates Kabupaten Jember. Journal of Social and Agricultural Economics Vol.4 No.1, 24-36.

Khatri, K., Shrestha, R., \& Mahat, U. (2012). Accessible Tourism: A Study of Accessibility in Hotel Chains, Public Transportation, and Ferry. Kerava: Laurea University of Applied Sciences.

Ki, B. M. (2016, September 27). United Nation. Retrieved from UN News: https://news.un.org/en/story/2016/09/541232-accessible-tourism-will-benefit-everyonesay-senior-un-officials-world-day 
Lestari, N. S., Wiastuti, R. D., \& Adiati, M. P. (2017). Implementasi Accessible Tourism Pada Bus Wisata Jakarta Explorer 'MPOK SITI'. Jurnal Hospitality dan Pariwisata, , 243-255.

Luiza, S. M. (2010). Accessible Tourism-The Ignored Opportunity. Annals of Faculty of Economics, University of Oradea, 1154-1157.

Masruroh, R. (2017). The Impact of Modern Retail Minimarket towards the Continuity of Traditional Retail Businesses. IOP Conf. Ser.: Mater. Sci. Eng (pp. 1-6). IOP Publishing Ltd.

Meath County Council. (n.d.). Retrieved September 03, 2018, from Accessible Parking: http://www.meath.ie/CountyCouncil/PayParking/AccessibleParking/

Natawidjaja, R. S. (2005). Modern Market Growth and Changing Map of Retail Food Sector in Indonesia. Pacific Food System Outlook (PFSO) 9th Annual Forecasters Meeting, (pp. 111). Kunming.

National Geographic. (n.d.). Retrieved September 01, 2018, from Urban Area: https://www.nationalgeographic.org/encyclopedia/urban-area/

Prabowo, E., Madi, S., Safri, \& Lustrilanang, P. (2017). Existence and Revitalization of Traditional Markets against Modern Markets Development. Journal of Basic and Applied Scientific Research, 1-16.

Schipmann, C., \& Qaim, M. (2011). Modern Food Retailers and Traditional Markets in Developing Countries: Comparing Quality, Prices, and Competition Strategies in Thailand. Economic Perspectives and Policy, 345-362.

Seminari, N. K., Rastini, N. M., \& Sulistyawati, E. (2017). The Impact of Modern Retail on Traditional Retail Traders in The Mengwi, Badung District. Udayana Journal of Social Sciences and Humanities, 35-43.

Silvia, A. (2013). Accessible Tourism in Italian Destination. 3rd International Conference on Tourism and Hospitality Management (pp. 8-28). Athens: Actions for the Development of Tourism and Tourism Education.

Sinaga, P. (2006). Makalah Pasar Modern VS Pasar Tradisional. Jakarta: Kementrian Koperasi dan UKM.

Somantri, G. R. (2005). Memahami Metode Kualitatif. MAKARA, Sosial Humaniora Vol.9 No.2, 57 65.

Stange, J., \& Brown, D. (2013, March 18). Tourism Destination Management (Achieving Sustainable and Competitive Results). Washington: Solimar International.

Sunanto, Sandra. (2012). Modern Retail Impact on Store Preference and Traditional Retailers in West Java. Asian Journal of Business Research Vol.2 No.2, 7-23. Bandung: Parahyangan Catholic University

UNWTO. (2011). Annual Report 2011. Madrid: World Tourism Organization.

UNWTO. (2013, November). Retrieved from http://cf.cdn.unwto.org: http://cf.cdn.unwto.org/sites/all/files/pdf/unwto_annual_report_2013_0.pdf 
UNWTO. (2015). Manual on Accessible Tourism for All - Public-Private Partnerships and Good Practices. Madrid: World Tourism Organization and Fundación ACS.

UNWTO. (2016). ethics.unwto.org. Retrieved September 03, 2018, from Accessible Tourism: http://cf.cdn.unwto.org/sites/all/files/docpdf/wctemessagesonaccessibletourism.pdf

Wiastuti, R. D., Adiati, M. P., \& Lestari, N. S. (2018). Implementation of Accessible Tourism Concept at Museums in Jakarta. IOP Conf. Series: Earth and Environmental Science. IOP Publishing. 